УДК 355.133:159.9 (477)

DOI https://doi.org/10.26661/2310-4368/2020-2-5

\title{
ВПЛИВ МОТИВАЦІЇ ДО СЛУЖБИ В АРМІЇ НА СОЦІАЛЬНО-ПСИХОЛОГІЧНУ АДАПТАЦІЮ ВІЙСЬКОВИХ КОНТРАКТНОЇ ТА СТРОКОВОЇ ФОРМ СЛУЖБИ
}

\author{
Миропольцева Н. I. \\ кандидат психологічних наук, \\ дочент кафедри психологіі \\ Чорноморський національний університет імені Петра Могили \\ вул. 68 Десантників, 10, Миколаїв, Україна \\ orcid.org/0000-0003-0548-9266 \\ Ninokshilova21@gmail.com
}

Пахомова О. В.

студентка

Чорноморський національний університет імені Петра Могили

вул. 68 Десантників, 10, Миколаїв, Україна

orcid.org/0000-0001-9976-8172

pahomovaolga20177@gmail.com

\section{Ключові слова: \\ військовослужбовиі, \\ мотивачзйна сфера, \\ адаптованість, \\ дезадаптованість, емоиійна \\ сфера, внутрішні мотиви, \\ зовнішні мотиви, особистість, \\ психологічний клімат.}

У статті представлено результати валідизації опитувальника «Шкала прощення як риси характеру» на українській вибірці 3402 осіб (204 жінок і 198 чоловіків): 224 студентів віком від 19 до 23 років, які здобувають першу вищу освіту, й 178 студентів віком від 24 до 45 років, які здобувають другу вищу освіту.

Концепт прощення розглядається як процес свідомої відмови особи від образи, гніву, ненависті, обурення, суму, зумовлених несправедливим ставленням інших людей до неї, та заміни негативних почуттів нейтральнішими й, нарешті, позитивними, такими, як співчуття, жалість, що супроводжуються позитивними думками стосовно кривдника й припиненням його засудження.

Показано, що прощення як диспозиціональна риса засновується на усвідомленні власних емоцій і здатності керувати ними, а також на здатності й готовності проявляти емпатію щодо кривдника.

У ході валідизації встановлено прийнятні показники надійностіузгодженості опитувальника. Представлено результати перевірки конвергентної та дивергентної валідності, ретестової надійності.

Емпіричні результати свідчать про належну надійність і валідність опитувальника «Шкала прощення як риси характеру».

Проаналізовано кореляції з показниками глибинної готовності до пробачення, емпатії, співробітництва, комунікативної компетентності, мстивості, агресивного типу міжособистісних стосунків, вираженістю симптомів тривоги й депресії.

Виявлено прямий значущий кореляційний зв'язок між показником прощення як риси характеру й інтегральним показником глибинної готовності до пробачення, емпатією, комунікативною компетентністю та співробітництвом як типом міжособистісних стосунків.

Емпірично встановлено зворотній значущий кореляційний зв'язок показника прощення як риси характеру 3 схильністю до мстивості, агресивним типом міжособистісних стосунків, із вираженістю симптомів тривоги й депресії. 
Опитувальник «Шкала прощення як риси характеру»є інформативним методичним інструментом, який може бути рекомендований до використання в психологічній консультативній роботі й в дослідницьких цілях.

\title{
THE INFLUENCE OF MOTIVATION FOR SERVICE IN THE ARMY ON THE SOCIO-PSYCHOLOGICAL ADAPTATION OF MILITARY CONTRACT AND TERM FORMS OF SERVICE
}

\author{
Myropoltseva N. I. \\ Candidate of Psychological Sciences, \\ Associate Professor at the Psychology Department \\ Petro Mohyla Black Sea National University \\ 68 Desantnykiv str., 10, Mykolaiv, Ukraine \\ orcid.org/0000-0003-0548-9266 \\ Ninokshilova21@gmail.com \\ Pakhomova O. V. \\ Student \\ Petro Mohyla Black Sea National University \\ 68 Desantnykiv str., 10, Mykolaiv, Ukraine \\ orcid.org/0000-0001-9976-8172 \\ pahomovaolga20177@gmail.com
}

Key words: servicemen, motivational sphere, adaptability, maladaptation, emotional sphere, internal motives, external motives, personality, psychological climate.
This article considers the approaches of domestic and foreign representatives of psychological areas on the concept of socio-psychological adaptation of civil servants. Theoretical analysis of psychological features of motivational sphere of servicemen is carried out. The main criteria that affect the personality of the military are activities associated with risk to life, physical activity, constant submission to management, distance from family and friends. It is determined that the socio-psychological adaptation of a young soldier depends on the psychological climate in the team and motivation for service. Motivation to serve in the army is the main factor influencing a person in deciding to serve, signing a contract. The structure of the motivational sphere of a serviceman is determined. It consists of internal motivation (one's own intentions and desire to perform this type of activity) and external motivation (the influence of the desire to achieve a certain social status, monetary reward, or pressure from the outside). The social and psychological adaptation of servicemen of the Nikolaev regional military commissariat is empirically investigated. The predominance of a high level of adaptation in military conscription and contract forms of service has been established. Differences in the levels of social and psychological adaptation of servicemen according to the form of service (contract or term) were analyzed using the Student's t-test. The motivational sphere of servicemen was studied, as a result of which there was a predominant external positive motivation. The discrepancies between the experimental data on the motivation of servicemen according to the form of service (contract or term) were assessed using the Student's t-test. An analysis of the correlations between the results of external positive motivation and a high level of socio-psychological adaptation of the military. 
Постановка проблеми. Нестабільна соціально-економічна та політична ситуація в країні зумовлює необхідність звернення уваги до однієї із важливих сфер державного життя - військової. На сьогодні активно збільшується кількість бажаючих вступити на контрактну службу, зростає зацікавленість молодого покоління у такому напрямі. Але проблема полягає у недостатньому усвідомленні всієї специфіки військового життя, мотивів, із якими особи входять у лави Збройних сил України. Через це виникає все більше випадків неадаптованості бійців: швидкого вигорання військових, дезертирства, виникнення тривалої емоційної нестабільності, що іноді призводить до неконтрольованої поведінки із використанням зброї.

Стосовно зазначеної проблематики можна виокремити такі напрями досліджень, які стосуються аспектів соціально-психологічної адаптації особистості (Г.А. Балл, А.А. Налчяджян, В.А. Тихоненко), суїцидальної поведінки військовослужбовців (I.I. Приходько, Я.В. Мацегора, О.С. Колесніченко, Ю.Б. Мельник), психологічної підготовки та психологічної бойової готовності військових в армії (В.Я. Білий, О.М. Кокун), структури мотиваційної сфери професійної діяльності військовослужбовців за контрактом (А.В. Сірий), психологічного супроводу для покращення соціально-психологічної адаптації військовослужбовців строкової служби (Г.В. Ложкін, В.І. Мозговий). Однак у практиці наукових досліджень відсутній системний підхід до вивчення впливу провідних мотивів на рівень соціально-психологічної адаптації військовослужбовців різної форми служби. Таким чином, соціальна значущість проблеми та іiі недостатнє вивчення в психології зумовили вибір теми цього наукового дослідження.

Мета статті - теоретично обгрунтувати та емпіричним шляхом визначити вплив мотивації до служби в армії (на прикладі строкової та контрактної форм служби) на процес соціальнопсихологічної адаптації військового.

Виклад основного матеріалу дослідження. Проблема соціально-психологічної адаптації військовослужбовців та їі особливостей привернула увагу багатьох вітчизняних та зарубіжних дослідників.

За Ю.Б. Мельник [7, с. 470], адаптація військовослужбовців являє собою два відносно самостійні процеси послідовного входження їх спочатку в колективи навчальних підрозділів (первинна адаптація), а потім - у колективи бойових підрозділів (вторинна адаптація). Дослідник розглянув і сферу взаємин у військовому колективі, що, безсумнівно, відіграє велику роль у соціально-психологічній адаптації, виділивши такі головні процеси: 1) встановлення взаємин у системі «підлеглий-начальник»; 2) встановлення взаємин у системі службового та особистого спілкування між товаришами по службі; 3) встановлення відносин між особистістю новобранця i військовим колективом.

Вступаючи в армійське життя, людина вже має певний досвід встановлення взаємин у колективі (в сім'ї, школі, навчальному закладі, неформальному колективі), вона має деякі уявлення про службу в армії, хоча вони можуть бути не зовсім адекватними та не відповідати реальності. Збіг (або неспівпадіння) ціннісних орієнтацій військового колективу і особистості, що туди входить, $є$ основою їх взаємодії і підгрунтям адаптованості.

А.А. Кузнєцов виділяє два рівні адаптації військового, що залежить від взаємного ставлення особистості і колективу до цінностей одне одного: рівень поверхневої адаптації, рівень глибинної адаптації [5, с. 83].

Зауважимо, що велика кількість дослідників приділяла увагу питанням соціально-психологічної адаптації військовослужбовців, виділяючи різні іï етапи та стадії. Більшість із них виділяе такі три фази адаптації, як: початкова фаза як відповідна психічна реакція організму на нові умови, друга фаза - фаза перебудови пристосувальних механізмів, динамічного стереотипу і психічних процесів; третя фаза - період стійкої адаптації, коли в основному завершується або завершено формування динамічного стереотипу і пристосувальних реакцій.

У сучасній психологічній літературі можна побачити такі етапи: пізнавальний, навчання нових способів поведінки, психологічної переорієнтації, вироблення звичок, внутрішнього прийняття нових завдань і умов діяльності. У процесі переходу від етапу до етапу адаптації у військового відбувається розширення знань, оволодіння способами і прийомами нових дій, послідовне зростання упевненості, змінюється ставлення до нових задач і умов діяльності, що сприяе формуванню якісних змін, які дозволяють йому успішно здійснювати нові види діяльності [8, с. 61].

Залежно від отриманого досвіду у військового формується власне ставлення до виконання вимог військової служби. В.Я. Білий виділяє їх такі типи, як: активно-позитивне; пасивне; активно-негативне [2, с. 17] .

Автор звертає увагу, що тип ставлення до несення військової служби може проявлятися у певних видах діяльності, наприклад у громадській. Виділяються види адаптації, що виходять із видів діяльності військовослужбовців: адаптація до навчальної діяльності (дидактична), військово-функціональна (професійно-бойова), адаптація до службової діяльності (службово-функціональна), адаптація до громадської діяльності в 
колективі (громадська), адаптація до умов побуту військового колективу (повсякденно-побутова).

У вищезазначених видах адаптації С.I. Яковенко виділяє 5 рівнів: дуже низький (негативний); низький (пасивний); середній (активний), високий (активно-продуктивний); дуже високий (творчий). Дослідник зазначає, що від рівня адаптованості залежить продуктивність військового під час виконання своїх обов'язків та задач, адже це досить складний динамічний, багаторівневий і багатосторонній процес, у якому відбувається перебудова потреб, мотиваційної сфери, змінюються уміння і звички відповідно до нових завдань та цілей, на які впливають умови їх реалізації [13, с. 266].

Основними чинниками, які впливають на якість перебігу соціально-психологічної адаптації, є індивідуальні характерологічні особливості військового. Тут I.I. Приходько виділяє низку факторів, що ускладнюють адаптацію, а саме: 1) неосвіченість; 2) виховання в несприятливих сім'ях, без батьків, у дитячих будинках; 3) національні особливості, нетерпиме ставлення до інших національностей; 4) фізична слабкість, не досить міцне здоров'я; 5) нервово-психічна нестійкість [9, c. 175].

Велике значення в процесі соціально-психологічної адаптації має спрямованість ціннісних орієнтацій військового. За умови, якщо він ще до служби активно брав участь у суспільному житті навчального або виробничого колективу, адаптація проходитиме швидко, орієнтовно протягом перших двох або трьох місяців.

Окрім особистісних чинників, які впливають на перебіг соціально-психологічної адаптації, сучасні вітчизняні дослідники виділяють ще об'єктивні (зовнішні): 1) труднощі військової служби: новий ритм життя, строгий розпорядок дня, обмеження особистої свободи; 2) розлука 3 будинком, сім'єю, звичним оточенням; 3) невдачі по службі, конфлікти 3 керівництвом і товаришами по службі; 4) надмірна строгість, завищені вимоги, несправедливість $[4 ; 6 ; 12]$.

Отже, результатом соціально-психологічної адаптації військовослужбовця $\epsilon$ адаптованість, яку можна охарактеризувати як стан взаємодії особистості солдата та військового колективу, за якого він без особливих зовнішніх і внутрішніх конфліктів ефективно виконує свою провідну діяльність і йде назустріч тим очікуванням, які вимагає від нього військова частина. Крім цього, військовослужбовець розвивається, досягає особистісних цілей, активно реалізує свої творчі здібності. Ефективність адаптації залежить від того, наскільки солдат може реально оцінити свої потреби, порівняти їх 3 наявними можливостями та усвідомлює мотиви своєї поведінки. Не досить сформоване уявлення про себе призводить до порушення адаптації, що може супроводжуватися підвищеною конфліктністю, порушенням взаємин, зниженням працездатності та погіршенням стану здоров'я.

Процес соціально-психологічної адаптації військовослужбовців, його перебіг та ефективність здебільшого залежить від усвідомлення мотивів, які спонукали особу прийняти рішення до служби в армії. Мотивація людей, які свідомо вибирають військову службу, завжди викликала особливий інтерес сучасних науковців. Мотиви вступу на військову службу розглядаються як усвідомлена, психологічна причина, яка спонукала безпосередньо громадянина до прийняття рішення про добровільне укладення відповідного контракту.

Мотивація військовослужбовців до професійної діяльності зумовлює характер організаційної поведінки і чинить істотний вплив на результативність і ефективність повсякденної діяльності. О.Б. Бобков та Г.А. Виноградова зазначають, що формування стійкої позитивної мотивації солдатів до проходження військової служби є найважливішим завданням старшого керівництва збройних формувань [3, с. 17].

Р.В. Ткачев визначає професійну мотивацію як систему спонукальних механізмів, спрямованих на оволодіння військовою професією та самореалізацію в ній. Основними структурними компонентами, що визначають особливості розвитку професійної мотивації, є: професійні мотиви, професійні цінності, а також інтереси, схильності, здібності, індивідуально-типологічні особливості та інші якості особистості [11, с. 46].

Питання мотивації до військової служби зарубіжні дослідники часто розглядають крізь призму інституційно-прагматичної теорії. Двом моделям армії відповідають інституційний і прагматичний типи мотивації до вступу на військову службу та iii продовження.

Американський дослідник Д. Гріффіт до інституційних відносить внутрішні мотиви: патріотизм, бажання випробувати себе, бажання бути корисним країні і суспільству. Прагматична мотивація служби означає ставлення до армії як роботодавця на ринку праці, який робить привабливу пропозицію. Дослідження Д. Гріффіта показали, що інституційна мотивація краща за прагматичну, оскільки військовослужбовці 3 такою мотивацією служать в армії значно довше прагматиків $[1$, c. 18$]$.

Ю.О. Бабаян підкреслює, що 3 90-х років $\mathrm{XX}$ століття головними цінностями виступають самореалізація, отримання задоволення від роботи, взаємоповага. Але автор зауважує, що армія не може і не повинна будуватися відповідно до прагматичної моделі військової служби як 
роботи. Більше того, військовослужбовці можуть розділяти одночасно інституційні та прагматичні цінності, тобто має місце змішаний тип мотивації $[1$, c. 18$]$.

Аналіз дослідження П. Бурі показав, що солдати, які вступили на службу 3 інституційних мотивів, налаштовані на більш тривалий термін служби і мобілізовувалися з резерву з причини, що становить внутрішню мотивацію. Солдати 3 прагматичною мотивацією були менш задоволені всіма умовами військової служби і мобілізовувалися 3 міркувань дотримання контракту. Автор робить висновок, що агітаційні кампанії, що акцентують увагу на фінансових привілеях військової служби, можуть залучити в армію менш лояльних і відданих військовослужбовців, яких складніше буде утримати в армії на тривалий термін.

Аналогічних висновків доходить Т. Вудраф. Внутрішні мотиви, такі як альтруїстичне служіння і особистісний розвиток, створюють більш сильний зв'язок 3 армією і військовими цінностями, ніж зовнішні мотиватори, такі як зарплата, отримання досвіду для майбутньої роботи, фінансування освіти та інші [1, с. 20].

Дослідження норвезьких військових психологів показують, що інституційна і професійна орієнтації можуть співіснувати, і військовослужбовець, зацікавлений в оплаті праці, пільгах та економічному добробуті, необов'язково є поганим солдатом. В умовах виконання міжнародних місій за межами рідної країни складно підтримувати ідеалістичні уявлення про військову службу, однак саме вірність традиційним військовим ідеалам, як показують дослідження, $є$ кращим мотиватором до служби і чинником ефективності військової організації.

Спроби класифікації військовослужбовців за типом мотивації робилися і вітчизняними психологами. Р.В. Ткачов виділив чотири мотиваційні типи офіцерів Військово-повітряних сил: матеріальний мотиваційний тип; кар'єрний мотиваційний тип; патріотичний мотиваційний тип; уникаючий мотиваційний тип [11, с. 49].

О.Б. Бобков виділяє три ієрархічні рівні залежно від характеру прояву військово-професійної мотивації, описуючи бачення особистості себе в ролі захисника, бажання стати ним, прийняття та задоволення умовами служіння (на першому рівні) та намагання уникнути військової служби за призовом, повну незадоволеність вимогами служби (на третьому рівні) [3, с. 17].

Варто зазначити, що нині ми спостерігаємо процес, коли збільшується кількість жіночої частини населення серед військовослужбовців. С.А. Риков називає такі мотиви прагнення жінок до військово-професійної служби: стабільне соціальне становище, грошове утримання, соціальні пільги та реальні гарантії порівняно 3 можливостями сучасного ринку праці та цивільного життя. Можна безкоштовно отримати освіту, оволодіти спеціальностями, які стануть у нагоді в майбутньому. Це одна сторона мотивації вибору - матеріальна. Але не менш важлива і духовна, а саме можливість влаштувати особисте життя, знайти друзів, продовжити сімейні традиції $[10$, с. 5].

Узагальнюючи теоретичні дослідження мотиваційної сфери військовослужбовців, можна зробити висновок, що мотивація до військової служби є одним із найбільш визначальних компонентів, які мають вплив на соціально-психологічний стан особистості солдата. Головними мотивами виступають внутрішні, такі як прагнення до самореалізації, патріотизм, бажання особистісного росту і розвитку; та зовнішні: матеріальна зацікавленість, отримання досвіду, фінансування освіти тощо. Мотивація може змінюватись у процесі служби, тому головним завданням вищого військового керівництва і політики країни загалом $€$ підкріплення та утримання позитивної мотивації та ставлення військовослужбовця до служби, бо від них безпосередньо залежить безпека держави.

Виходячи зі структури мотиваційної сфери військовослужбовця, для досягнення мети та розв'язання поставлених завдань ми визначили такі етапи експериментального дослідження:

1. Здійснити порівняльний аналіз та охарактеризувати рівні соціально-психологічної адаптації військовослужбовців контрактної та строкової форми служби.

2. Визначити кількісні та якісні характеристики мотиваційної сфери військовослужбовців різних форм служби.

3. Провести математично-статистичну обробку співвідношення рівня соціально-психологічної адаптації та провідних мотивів солдат.

Дослідницько-експериментальна робота виконувалася на базі Миколаївського обласного військового комісаріату. У ній взяли участь 46 військовослужбовців жіночої та чоловічої статі контрактної форми служби віком від 20 до 56 років та 46 військовослужбовців чоловічої статі строкової служби віком від 18 до 25 років.

Для організації емпіричного дослідження були використані методики «Мотивація професійної діяльності Замфір» та методика «Дослідження соціально-психологічної адаптації» К. Роджерса, Р. Даймонда.

Методика «Дослідження соціально-психологічної адаптації» К. Роджерса, Р. Даймонда спрямована на виявлення особливостей адаптаційного процесу особистості через інтегральні показники «адаптація», «самоприйняття», «прийняття інших», «емоційна комфортність», «інтерналь- 
ність», «прагнення до домінування». Кожен з наведених показників розраховується за емпірично виведеною формулою. Інтерпретація результатів опитування здійснюється за нормативами, що відрізняються залежно від віку тестованого.

Для діагностики мотивації професійної діяльності військовослужбовців нами була використана методика «Мотивації професійної діяльності» К. Замфір у модифікації А. Реана.

Методика може застосовуватися для діагностики мотивації професійної діяльності. В ії основі $€$ концепція про внутрішню і зовнішню мотивації. Зазначимо, що внутрішня мотивація передбачає той факт, що діяльність для особистості є безпосередньо важливою, тоді як в основі зовнішньої мотивації професійної діяльності лежить прагнення до задоволення інших потреб, зовнішніх стосовно змісту самої діяльності (мотиви соціального престижу, зарплати). Самі зовнішні мотиви автори розділяють на зовнішні позитивні і зовнішні негативні. Опитуваному потрібно прочитати наведені мотиви професійної діяльності і дати оцінку їх значущості за п'ятибальною шкалою.

На підставі отриманих результатів визначається мотиваційний комплекс особистості - співвідношення між собою трьох видів мотивації: ВМ, ВПМ та ВВП.

До кращих, оптимальних мотиваційних комплексів слід відносити такі два типи поєднань: $\mathrm{BM}>\mathrm{B \Pi M}>\mathrm{BOM}$ і ВM $=$ ВПМ $>$ ВОМ. Найгіршим мотиваційним комплексом $\epsilon$ тип $\mathrm{BOM}>$ ВПМ> ВМ. Будь-які інші поєднання є проміжними 3 точки зору їх ефективності.

Для інтерпретації результатів враховувалося не тільки мотиваційне співвідношення, а й показники окремих видів мотивації.

Результати, отримані за методикою «Дослідження соціально-психологічної адаптації» К. Роджерса, Р. Даймонда, показали такі дані. Низький рівень адаптації (0-39 балів) мають 7,7\% опитуваних. Це може свідчити, що військовослужбовець може негативно висловлюватися про службу, керівництво, скаржитися на здоров'я, часто змінюе настрій, спостерігаються порушення дисципліни, не засвоює необхідний матеріал, нерегулярно або недобросовісно виконує поставлені перед ним завдання, може проявляти грубість, важко входить у контакт із товаришами по службі, не проявляє ініціативності, громадської активності, доручення виконує під керівництвом.

Середній рівень адаптації (40-60 балів) має $36,5 \%$ опитуваних. Такі військовослужбовці позитивно ставляться до служби, розуміють і самостійно виконують поставлені завдання, «включаються» тільки тоді, коли їм цікаво, але повністю віддаються справі, старанно виконують громадські доручення, мають багато дружніх зв'язків серед товаришів по службі.

Високий рівень адаптації (61-100 балів) має $55,8 \%$ військовослужбовців. Їх можна охарактеризувати як добре пристосованих до нових умов, ініціативних, бажаючих досягти кар'єрного зростання. Вони позитивно ставляться до служби, керівництва і товаришів по службі, легко знаходять спільну мову з ними, старанно і відповідально приступають до виконання поставлених завдань, проявляють великий інтерес до військової справи.

Якщо зробити оцінку розбіжностей експериментальних даних соціально-психологічної адаптації військовослужбовців відповідно до форми служби (контрактної чи строкової) за допомогою t-критерію Ст'юдента для незалежних вибірок, то маємо результати, які вказані у таблиці 1.

Додатний знак перед значенням t-критерію Ст'юдента вказує на те, що такий показник за значенням вищий у першій групі (строкова форма служби), від'ємний знак вказує на те, що такий показник вищий у другій групі (контрактна форма служби).

Відповідно до табличних значень для такої кількості вибірки критичний t-критерій Ст'юдента дорівнює 2,66, отже, можна зробити висновок, що всі емпіричні показники таблиці 1 увійшли у зону значущості. Встановлено значимі відмінності між рівнем соціально-психологічної адаптації військовослужбовців строкової та контрактної форм служби. Можна зробити висновок, що військовослужбовці контрактної служби проходять швидше і якісніше початкові етапи соціально-психологічної адаптації, почуваються комфортно в армійському колективі і вважають себе його часткою.

Таблиця 1

Оцінка розбіжностей результатів методики «Дослідження соціально-психологічної адаптації» відповідно до форми служби в армії

\begin{tabular}{|c|c|c|c|}
\hline $\begin{array}{c}\text { Порівняння } \\
\text { контрактної та } \\
\text { строкової форм } \\
\text { служби }\end{array}$ & $\begin{array}{c}\text { Інтегральний показник } \\
\text { адаптації }\end{array}$ & Адаптивність & Дезадаптивність \\
\hline t-критерій & $-1,78$ & $-1,95$ & 2,22 \\
\hline
\end{tabular}


Для дослідження мотиваційної сфери військовослужбовців було вибрано методику К. Замфір у модифікації А. Реана «Мотивація професійної діяльності». За результатами такої методики було встановлено, що у $27 \%$ опитуваних військовослужбовців переважає внутрішня мотивація до служби в армії. Це означає, що військові отримують задоволення від процесу своєї діяльності, вони не орієнтовані на матеріальні блага, тут мотивом $\epsilon$ відчуття ефективності, а результатом активності $€$ зростання різного роду компетентності. $36 \%$ мають зовнішню позитивну мотивацію: їхнє бажання служити підкріплене матеріальною стороною, соціальними аспектами, такими як пільги, соціальний статус, влада, престиж. 14\% мають зовнішню негативну мотивацію. Це $є$ ознакою тиску зі сторони, бажання уникнути покарання, відчуття небезпеки через уникнення впливу. Змішані типи мотивації мають 23\% опитуваних: $15 \%$ поєднують внутрішню та зовнішню позитивну мотивацію (підкріплюють власне бажання служити різними привілеями цієї діяльності) та $8 \%$ поєднали зовнішню позитивну та негативну мотивацію (керуються вигодою, яку отримують від служби, та страхом тиску ззовні).

Якщо зробити оцінку розбіжностей експериментальних даних мотивації військовослужбовців відповідно до форми служби (контрактної чи строкової) за допомогою t-критерію Ст'юдента для незалежних вибірок, то маємо результати, які вказані у таблиці 2.

Додатний знак перед значенням t-критерію Ст'юдента вказує на те, що такий показник за значенням вищий у першій групі (строкова форма служби), від'ємний знак вказує на те, що такий показник вищий у другій групі (контрактна форма служби).

Відповідно до табличних значень для такої кількості вибірки критичний t-критерій Ст'юдента дорівнює 2,66, отже, можна зробити висновок, що всі емпіричні показники таблиці 2 увійшли у зону значущості. Встановлено значимі відмінності між внутрішньою, зовнішньою позитивною та зовнішньою негативною мотивацією військовослужбовців строкової та контрактної форм служби. Можна зробити висновок, що військовослужбовці контрактної служби мають вищу внутрішню та зовнішню позитивну мотивацію, військовослужбовці строкової служби мають вищу зовнішню негативну мотивацію.

Для встановлення взаємозв'язку між рівнем мотивації та адаптації був застосований кореляційний аналіз методом рангової корекції Спірмена. Порівнянню піддавались такі шкали, як: інтегральний показник адаптації методики «Дослідження соціально-психологічної адаптації» К. Роджерса, Р. Даймонда та показник рівня зовнішньої позитивної мотивації за методикою К. Замфір у модифікації А. Реана «Мотивація професійної діяльності». Було отримано такі результати: значення коефіцієнта кореляції дорівнює $\mathrm{r}=0,7101$. Отримане значення кореляції говорить про наявність прямого зв'язку між мотивацією та рівнем соціально-психологічної адаптації військовослужбовця, а величина коефіцієнта говорить про сильний зв'язок між цими критеріями. Тобто чим вищий показник зовнішньої позитивної мотивації, тим краще відбувається процес адаптації.

Висновки. Була досліджена соціально-психологічна адаптація військовослужбовців обласного військового комісаріату. Результати дослідження соціально-психологічної адаптації військовослужбовців Миколаївського обласного військового комісаріату показали, що бійці мають переважно високий рівень адаптації. Це є свідченням того, що сучасний громадянин України більшою мірою розуміє складність служби в армії, готовий до перешкод, фізичного та психологічного навантаження. Психодіагностичний зріз серед військовослужбовців відповідно до форми служби (контрактної чи строкової) за допомогою t-критерію Ст'юдента показав значимі відмінності між рівнем соціально-психологічної адаптації військовослужбовців строкової та контрактної форм служби. Результати дослідження мотиваційної сфери показали, що більшість військових мають переважаючу зовнішню позитивну мотивацію. Це $є$ ознакою їхнього бажання досягти кар'єрного росту, звання, отримувати нагороди, переваги військової служби, що підкріплюється матеріальним заохоченням 3 боку держави та керівництва.

Таблиця 2

\section{Оцінка розбіжностей результатів методики «Мотивація професійної діяльності» відповідно до форми служби в армії}

\begin{tabular}{|l|c|c|c|}
\hline $\begin{array}{c}\text { Порівняння контрактної } \\
\text { та строкової форм } \\
\text { служби }\end{array}$ & $\begin{array}{c}\text { Внутрішня мотивація } \\
\text { Зовнішня негативна } \\
\text { мотивація }\end{array}$ & $\begin{array}{c}\text { Зовнішня позитивна } \\
\text { мотивація }\end{array}$ \\
\hline t-критерій & $-1,86$ & 2,13 & $-2,31$ \\
\hline
\end{tabular}


Оцінка розбіжностей експериментальних даних мотивації військовослужбовців відповідно до форми служби (контрактної чи строкової) за допомогою t-критерію Ст'юдента встановила, що військовослужбовці контрактної служби мають вищу внутрішню та зовнішню позитивну мотивацію, військовослужбовці строкової служби мають вищу зовнішню негативну мотивацію. Аналіз результатів зовнішньої позитивної мотивації та високий рівень соціально-психологічної адаптації військових показав наявність сильного прямого зв' язку.

Проведене дослідження не вичерпує всіх аспектів зазначеної проблеми. Не менш важливим, на нашу думку, $є$ розроблення й апробація технологій психологічного супроводу осіб, які показали низький рівень соціально-психологічної адаптації шляхом змін у мотиваційній сфері, що і стане предметом подальших досліджень.

\section{ЛIТЕРАТУРА}

1. Бабаян Ю.О., Грішман Л.О. Особливості психологічної готовності військовослужбовців до дій в екстремальних умовах. Збірник наукових пращь. 2014. Випуск 2.13 (109). С. 17-21.

2. Білий В.Я. Медико-соціальні проблеми професійної надійності військовослужбовців у контексті національної безпеки України. Наука і оборона. 2009. №1. С. 16-20.

3. Бобков О.Б., Виноградова Г.А. Фактори, які впливають на навчально-професійну мотивацію студентів військового типу. Харків, 2012. 17 с.

4. Максименко С.Д., Олексієнко Б.М., Сафін О.Д. Військова психологія і педагогіка : підручник для військових вузів. Хмельницький : Видавництво НАПВУ, 2000. 562 с.

5. Кузнєцов А.А. Метафізичні теорії особистості. Київ, 2012. 219 с.

6. Маклаков А.Г. Военная психология. Санкт-Петербург, 2005. 464 с.

7. Мельник Ю.Б. Психологічне забезпечення і супровід військовослужбовців як засоби профілактики та подолання посттравматичних стресових розладів. Posttraumatic Stress Disorder: adults, children and families in a war situation: International scientific and practical edition. Vol. II. Warsawa. Kyiv : PAN Gnosis, 2018. Pp. 469-480.

8. Кокун О.М., Агаєв Н.А., Пішко І.О., Лозінська Н.С. Основи психологічної допомоги військовослужбовцям в умовах бойових дій : методичний посібник. Київ : НДЦ ГП ЗСУ, 2015. 170 с.

9. Приходько I.I. Засади психологічної безпеки персоналу екстремальних видів діяльності : монографія. Харків : Акад. ВВ МВС України, 2013. 745 с.

10. Рыков С.А. У армии теперь и мужское, и женское лицо. Независимое военное обозрение. 2005. № 28. C. 4-15.

11. Ткачев Р.В. Мотивація військово-професійної діяльності Повітряних Сил. Москва, 2013. 169 с.

12. Томчук M.I. Психологічна готовність особистості до правоохоронної діяльності : монографія. Хмельницький : Еврика; Поліграфіст, 2003. 154 с.

13. Яковенко С.І., Яковенко Т.М. Психічна стійкість військовослужбовців до впливу екстремальних чинників. Київ : КВГІ, 2008. С. 265-268.

\section{REFERENCES}

1. Babajan, Ju.O., Ghrishman, L.O. (2014). Osoblyvosti psykhologhichnoji ghotovnosti vijsjkovosluzhbovciv do dij v ekstremaljnykh umovakh [Features of psychological readiness of servicemen to act in extreme conditions]. Collection of scientific works. 2.13 (109). 17-21 [in Ukrainian].

2. Bilyj, V.Ya. (2009). Medyko-socialjni problemy profesijnoji nadijnosti vijsjkovosluzhbovciv u konteksti nacionaljnoji bezpeky Ukrajiny [Medical and social problems of professional reliability of servicemen in the context of national security of Ukraine]. Science and defense. 1. 16-20 [in Ukrainian].

3. Bobkov, O.B., Vynoghradova, Gh.A. (2012). Faktory, jaki vplyvajutj na navchaljno-profesijnu motyvaciju studentiv vijsjkovogho typu [Factors influencing the educational and professional motivation of military students]. Kharkiv [in Ukrainian].

4. Maksymenko, S.D., Oleksijenko, B.M., Safin, O.D. (2000). Vijsjkova psykhologhija i pedaghoghika: pidr. dlja vijsjkovykh vuziv [Military psychology and pedagogy: a textbook for military universities]. Khmeljnycjkyj: NAPVU [in Ukrainian].

5. Kuznjecov, A.A. (2012). Metafizychni teoriji osobystosti [Metaphysical theories of personality]. Kyiv [in Ukrainian].

6. Maklakov, A.Gh. (2005). Voennaja psykhologhyja [Military psychology]. Sankt-Peterburg [in Russian].

7. Meljnyk, Ju.B. (2018). Psykhologhichne zabezpechennja i suprovid vijsjkovosluzhbovciv jak zasoby profilaktyky ta podolannja posttravmatychnykh stresovykh rozladiv [Psychological support and accompaniment of servicemen as a means of prevention and overcoming of post-traumatic stress disorders]. Posttraumatic Stress Disorder: adults, children and families in a war situation: 
International scientific and practical edition. Vol. II. Warsawa. Kyiv: PAN Gnosis, Pp. 469-480 [in Ukrainian].

8. Kokun, O.M., Aghajev, N.A., Pishko I.O., Lozinsjka N.S. (2015). Osnovy psykhologhichnoji dopomoghy vijsjkovosluzhbovcjam $\mathrm{v}$ umovakh bojovykh dij: metodychnyj posibnyk [Fundamentals of psychological assistance to servicemen in combat: a manual]. Kyiv: NDC GhP ZS [in Ukrainian].

9. Prykhodjko, I.I. (2013). Zasady psykhologhichnoji bezpeky personalu ekstremaljnykh vydiv dijaljnosti: monograph [Principles of psychological safety of personnel of extreme activities: monograph]. Kharkiv: Akad. VV MVS Ukrajiny [in Ukrainian].

10. Rykov, S.A. (2005). U armyy teperj y muzhskoe y zhenskoe lyco [The army now has both male and female faces]. Independent Military Review. 28. 4-15 [in Russian].

11. Tkachev, R.V. (2013). Motyvacija vijsjkovo-profesijnoji dijaljnosti Povitrjanykh Syl [Motivation of military-professional activity of the Air Force]. Moskva [in Ukrainian].

12. Tomchuk, M.I. (2003). Psykhologhichna ghotovnistj osobystosti do pravookhoronnoji dijaljnosti: monoghrafija [Psychological readiness of the person for law enforcement activity: monograph]. Khmeljnycjkyj: Evrika; Polighrafist [in Ukrainian].

13. Jakovenko, S.I., Jakovenko, T.M. (2008). Psykhichna stijkistj vijsjkovosluzhbovciv do vplyvu ekstremaljnykh chynnykiv [Mental resilience of servicemen to the influence of extreme factors]. Kyiv: KVGh [in Ukrainian]. 